\title{
Foreign Exchange Markets: The Dollar in 1980
}

\author{
DALLAS S. BATTEN
}

F OREIGN exchange markets during 1980 were dominated by activity in domestic financial markets throughout the world. Dramatic changes in the direction of international capital flows during the year reflected the relatively volatile interest rate movements in the United States. While these interest rate movements appeared to be the major force affecting exchange rates during the period, however, rising rates of inflation and inflationary expectations, as well as midyear recessions in most industrial countries, also influenced exchange rate movements.

This article describes and analyzes what occurred in foreign exchange markets in the past year with special emphasis on changes in the value of the U.S. dollar. First, however, the framework necessary to analyze movements of exchange rates is presented. Next, changes in the value of the U.S. dollar are analyzed in detail. Finally, the activity of U.S. policymakers within foreign exchange markets during the year is investigated.

\section{ANALYTICAL FRAMEWORK}

The exchange rate between any two currencies is determined just as any other price is determined - by the interaction of demand and supply. For example, the U.S. dollar/deutschemark exchange rate is a result of the interaction between German consumers and investors demanding dollars (supplying deutschemarks) and U.S. consumers and investors supplying dollars (demanding deutschemarks). If, at the current deutschemark price of a dollar, a larger quantity of dollars is demanded than is supplied, the deutschemark price of a dollar will rise. If the quantity demanded is less than that supplied at the current price, the price of a dollar will fall.

Why do Americans demand deutschemarks? Americans demand deutschemarks simply because they want

to purchase goods and services produced in Germany or securities denominated in deutschemarks. On the other hand, Germans are willing to supply deutschemarks (in exchange for dollars) because they want to purchase U.S.-produced goods and services or dollardenominated securities. Consequently, the determinants of the dollar/deutschemark exchange rate are those factors that determine the demand for goods, services and securities in Germany and in the United States. Two of the most important determinants of the demand for and the supply of goods, services and securities (and consequently of exchange rates) are relative price levels and interest rates between countries.

\section{The Relationship Between Exchange \\ Rates and Price Levels}

If prices in the United States rise relative to those in Germany, U.S. demand for goods and services will shift away from those produced in the United States to those produced in Germany, other things equal. German demand will also shift away from U.S.-produced goods and services to domestically produced ones. The result of these shifts is that at every deutschemark price of the dollar, German consumers will want to purchase fewer dollars, while U.S. consumers will be willing to supply more dollars (i.e., demand more deutschemarks) than before. In other words, the demand for dollars has fallen, and the supply of dollars has increased, resulting in a fall in the deutschemark price of a dollar. Thus, a rise in U.S. prices relative to those in Germany causes the dollar to depreciate.

The price level in any country is determined by the relationship between the demand for and the supply of money; that is, it depends on the supply of money relative to the amount that individuals desire to hold. 
The quantity of money supplied is essentially a policy variable determined by monetary authorities. The demand for money is the individual's desire to hold a portion of his wealth in the form of money. The latter is determined by income, interest rates, prices and price expectations. The equilibrium price level is the one (given the level of income, interest rates and price expectations) that induces individuals to hold the exact quantity of money that monetary authorities are supplying. Any other price level will motivate individuals to hold more or less money than is being supplied. If individuals are satisfied with the amount of money that they are holding, they will have no desire to increase or decrease their spending on goods, services and securities. In other words, they are in equilibrium and the existing price level is the equilibrium one. If they desire to hold more or less of their wealth in the form of money (or if the money supply changes), however, they will alter their spending habits in order to reach equilibrium again and, consequently, the price level will change.

For example, if the supply of money in the United States is greater than the amount that individuals desire to hold, both an excess supply of money and a concomitant excess demand for goods, services and securities exist. In order to reduce their money holdings, individuals increase their spending on goods, services and securities, causing U.S. prices to rise. Likewise, if foreign individuals experience an excess supply of money, prices must also rise abroad. Other things equal, if excess money growth in the United States exceeds that in other countries, then prices will rise relatively more in the United States than they will in other countries.

Since changes in the foreign currency price of a dollar (the dollar exchange rate) are determined among other things by relative changes in the price levels here and abroad, and since price levels reflect relative rates of excess money growth, changes in the dollar exchange rates are caused primarily by differences in the rates of excess money growth across countries. That is, movements in exchange rates are primarily monetary phenomena reflecting relative differences in excess money growth. ${ }^{1}$ If money growth exceeds the growth in money demand relatively more in the United States than in other countries, the dollar will depreciate relative to other currencies. Over

For a discussion of this topic, see Jacob A. Frenkel, "A Monetary Approach to the Exchange Rate: Doctrinal Aspects and Empirical Evidence," in Jacob A. Frenkel and Harry G. Johnson, eds., The Economics of Exchange Rates (Reading, Massachusetts: Addison-Wesley Publishing Co., 1978), pp. 1-25. the long run, the value of currencies should adjust in order to offset relative differences in rates of inflation. This concept, called purchasing power parity, states that if prices in the United States rise by 10 percent relative to those in Germany, then the deutschemark price of a dollar should fall by 10 percent, other things equal.

\section{The Relationship Between Exchange \\ Rates and Interest Rates}

This monetary approach to exchange rate determination implicitly assumes that there is sufficient time for commodity markets to clear (reach equilibrium). However, financial markets also reflect relative changes in rates of excess money growth. Since financial markets typically adjust more rapidly than commodity markets, changes in interest rate differentials (i.e., the differences between interest rates in the United States and those in other countries) are usually the major determinants of exchange rate movements in the short run through their impact on the direction of international capital fows. However, it is changes in real, not nominal, interest rate differentials that actually motivate the international movement of capital and, therefore, induce changes in exchange rates.

The interest rates that are quoted in financial markets are nominal interest rates. Each nominal interest rate contains two components: the real interest rate (or real yield) and a premium for expected inflation. The real interest rate represents the compensation in terms of goods and services paid to the lender for the use of his money over some time period. The inflation premium is the compensation for the erosion of purchasing power during the life of the loan. The nominal interest rate is approximated by the sum of the two. ${ }^{2}$ The real interest rate is crucial because it alone influences the decision to lend; lenders are concerned

${ }^{2}$ For example, individual A lends $\$ 1,000$ to $B$ for one year; $A$ charges $B$ a nominal interest rate of 10 percent on the loan. At the end of one year, $B$ pays $A \$ 1,100$ (the amount borrowed plus $\$ 100$ interest). If the prices of goods and services have not changed during the year (i.e., if the inflation rate is zero), then A can purchase 10 percent more goods and services thar he could have purchased one year ago. In other words, the nominal interest rate and the real interest rate are the same. However, if prices, in general, have risen by 10 percent during the year, $A$ camnot buy any more today with $\$ 1,100$ than he could have bought a year ago with $\$ 1,000$. In essence, $A$ has gained nothing by lending to $B$ at a 10 percent nominal interest rate; $B$ has repaid the loan in dollars that are worth 10 percent less than the ones he borrowed. Even though the nominal interest rate is 10 percent, the real interest rate is zero. However, if $A$ expects prices to rise by 10 percent during the year, he could achieve his desired 10 percent teal rate of retum by lending to $\mathrm{B}$ at at nominal interest rate of 20 percent - the desired real interest rate plas the expected inflation premium. 
only with how much additional consumption they can obtain in the future in return for foregoing consumption today.

Investors (lenders) in international markets are searching for the market in which they can earn the highest real rate of interest. ${ }^{3}$ If an increase in inflationary expectations for the United States causes nominal interest rates to rise relative to those in Germany, investors will not transfer their funds from German to U.S. financial markets. These funds will move only if the increase in U.S. nominal interest rates reflects a rise in U.S. real interest rates relative to Germany.

The key to understanding short-run changes in the value of the dollar, then, is to distinguish changes in nominal interest rate differentials that are caused by changes in real interest rate differentials from those caused by relative changes in inflationary expectations. In particular, increases in nominal interest rate differentials resulting from increases in real interest rate differentials should raise the current value of the dollar, as foreign investors increase their demand for dollars in order to purchase dollar-denominated securities. On the other hand, increases in nominal interest rate differentials due to relatively higher inflationary expectations will not attract inflows of foreign capital and should not, by themselves, affect the current value of the dollar. However, expectations of a relatively higher rate of inflation in the United States will decrease the desire of foreigners to hold dollars for any purpose since they expect the purchasing power of the dollar to fall. ${ }^{5}$ Consequently, the current value of the dollar will decline. It is important to note that higher

In this statement it is implicitly assumed that risk is being held constant.

4To be technically correct, capital flows are determined by expected future exchange rates as well as interest rate differ. entials. In particular, foreign investors calculate their rates of return in their own currencies, not the foreign currencies in which their financial assets are denominated. When a German, for example, purchases a dollar-denominated security, he is guaranteed a return in dollars (when the security matures), not in deutschemarks. Consequently, the return to a German buying a dollar-denominated security depends not only on the U.S. interest rate but also on the dollar/deutschemark exchange rate when the security matures. In fact, changes in the dollar/deutschemark exchange rate may eliminate any interest rate advantage that the United States may have had To avoid this possibility, the foreign investor will typically sell the foreign currency proceeds of his investment forward (see footnote 6 below). In this nanner the forwatd exchange rate (which reffects the expected future exchange rate) also influences the direction of international capital tows. For a more detailed treatment of this topie, see Douglas $R$. Mudd, "Do Rising Interest Rates Imply a Stronger Dollar?" this Review (June 1979), pp. 12.13,

This change in the relative rates of inflationary expectations is a ramification, in financial markets, of a change in the relative rates of excess money growth across countries. inflationary expectations simultaneously motivate an increase in nominal interest rate differentials and a decline in the value of the dollar.

The relative importance of this concept is reflected in the movement of the forward exchange rate. In the forward foreign exchange market, currencies are bought and sold for future delivery, typically 30,90 or 180 days. ${ }^{6}$ The dollar exchange rate in the forward market reflects the expectations of market participants about what the spot (current) value of the dollar will be on some date in the future. For example, if the market expects that the value of the dollar will be lower in three months than it is today, the price of a dollar to be received or purchased at the end of three months (i.e., the three-month forward rate) will fall below the current value of the dollar.

If nominal interest rate differentials increase because inflationary expectations accelerate faster in the United States than in other countries, then no new foreign capital will flow into the United States. Because of this relative increase in inflationary expectations, the foreign exchange market will expect the future value of the dollar to fall. Consequently, the forward dollar exchange rate will fall, reflecting this lower expectation. In other words, an increase in nominal interest rate differentials caused by a relative increase in inflationary expectations should result in a decline in the forward exchange rate. Alternatively, if the increase in nominal interest rate differentials reflects an increase in real interest rate differentials, new foreign capital will be attracted into the United States, causing the current value of the dollar to rise. The forward rate should be virtually unaffected, although it could rise marginally, reflecting expectations of a stronger future value of the dollar.

To summarize, exchange rate movements in the long run are essentially monetary phenomena induced by relative changes in price levels across countries, which reflect different rates of excess money growth across comntries. On the other hand, in the short run exchange rate movements may be dominated by changes in financial asset markets transmitted via changing interest rate differentials. This does not imply that the

\footnotetext{
GTe forward foreign exchange market is used primarily by international traders and investors who have contracted to make or receive payment in a foreigo currency at a future date. These individuals are concerned that if the spot exchange rate changes before they make or receive their payment, they must make a greater than expected payment (or receive less than expected) in their own currency. By agreeng on a price today for a sale or a purchase of foreign currency in the future, the risk of exchange rate changes is eliminated.
} 
causes of short-run and long-run movements of exchange rates are mutually exclusive. Certainly, interest rate differentials reflect relative changes in inflationary expectations that result from relative changes in the rates of excess money growth across countries. However, there are forces other than inflationary expectations that influence the determination of interest rates within financial markets. Also, since these mar. kets adapt to changes (both real and monetary) much more rapidly than commodity markets do, changes in factors that influence the relative attractiveness of various financial assets have a greater impact on exchange rate movements in the short run.

\section{SHORT-PUN MOVEMENTS OF THE FOREIGN EXCHANGE VALUE OF THE DOLLAR}

In general, the dollar appreciated (on a tradeweighted basis) relative to other major currencies in 1980 , beginning the year at 85.15 and ending at $89.99 .^{7}$ The movement of the tradew weighted value of the dollar during 1980 can be segregated into three distinct periods. In the first quarter of 1980 the dollar was extremely strong, appreciating by 11 percent to its high for the year of 94.64 on April 7. During the next three months this movement was reversed as the value of the dollar declined to 84.04 , its low for the year. Since then the dollar has steadily appreciated (except for a short period in late August), closing the year at $89.99,10$ percent above its low and 5.7 percent above its value at the beginning of the year.

Changes in short-term interest rate differentials have motivated these short-run changes. Chart 1 shows that, since the fourth quarter of 1979 , the trade-weighted value of the dollar has moved directly with a weighted average of three-month nominal interest rate differentials. This suggests that short-run changes in the value of the dollar during this period have been motivated primarily by changes in real interest rate differentials, a positive relationship that contrasts sharply with the negative one that existed from 1978 to the third quarter of 1979. In fact, since the present system of floating exchange rates began in 1973 , a negative

\footnotetext{
The trade-weighted average exchange rate is a geometric Inean of the value of the dollar against 10 other currencies weighted by average trade shares. The countries included are Belgium, Canada, France, Gemany, Italy, Japan, the Netherlands, Sweden, Switzerland and the United Kingdom. For a more detailed explanation, see "Index of the Weighted Average Exchange Value of the U.S. Dollar: Revision," Federal Reserve Bulletin (August 1978), p. 700 .
}

relationship has been the rule, not the exception. ${ }^{8}$ Consequently, it appears that relative changes in inflationary expectations have greatly influenced the short-rum movement of the value of the dollar during this period.

One explanation for this reversal involves the change in monetary control procedures that the Federal Reserve initiated in October 1979. Before then, the Federal Reserve used the federal funds rate as an intermediate target in its attempt to control the money supply. This procedure resulted in frequently missed monetary growth targets, primarily because the Federal Reserve was unwilling to change the federal funds rate target as often and by as much as necessary to achieve the targeted monetary growth. In other words, the Fed tolerated money growth volatility in order to limit short-run variations in nominal interest rates.

A by-product of this procedure was that the Fed smoothed short-run variations in real interest rates by typically supplying sufficient reserves to accommodate changes in the banking system's liquidity demands. ${ }^{9}$ The changes in nominal interest rates that did occur were inadequate to keep money growth on target and were outweighed by variations in inflationary expectations. As a result, nominal dollar interest rates were negatively correlated with real dollar interest rates during this period. ${ }^{10}$

Since October 1979 the Fed has more directly controlled the money supply by focusing more on controlling the growth of reserves in the banking system and less on smoothing interest rates. Thus far, both

\footnotetext{
SSee Mudd, "Do Rising Interest Rates Imply a Stronger Dollar:" pp. 9-13 and Michael Keran and Charles Pigott, "Interest Rates and Exchange Rates: The Relationship," Federal Reserve Bank of San Francisco Weekly Letter (September $12,1980)$.

5See Michael Keran and Charles Pigott, "Interest Rates and Exchange Rates: Policy Implications," Federal Reserve Bank of San Francisco Weekly Letter (September 19, 1980).

${ }^{10}$ Using a simple autoregressive model of past rates of inflation to predict expected rates of inflation, the real interest rate and expected inflation preminm components of a nominal interest rate can be estimated (see chart 2). During the I/1978 to III/1979 period the standard deviation of the three-month commercial paper rate (a nominal interest rate) in the United States is 1.57; the standard deviation of the projected inflation rate is 2,03 ; the standard deviation of the difference between the two (an estrmate of the real interest rate) is 1.17 . For the IU/1979 to IV/1980 period the standard deviation of the three-month commercial paper rate in the United States is 3.07 ; the standard deviation of the projected inflation rate is 2,30 ; the standard deviation of the estinated real interest rate is 3.46 . Clearly, the variability of nominal interest rates in the first period was dominated by changing inflationary expectations while in the second period it was dominated by changes in the real interest rate.
} 


\section{Chort 1 \\ Foreign Exchange Value of the Dollar and Interest Rate Differential}

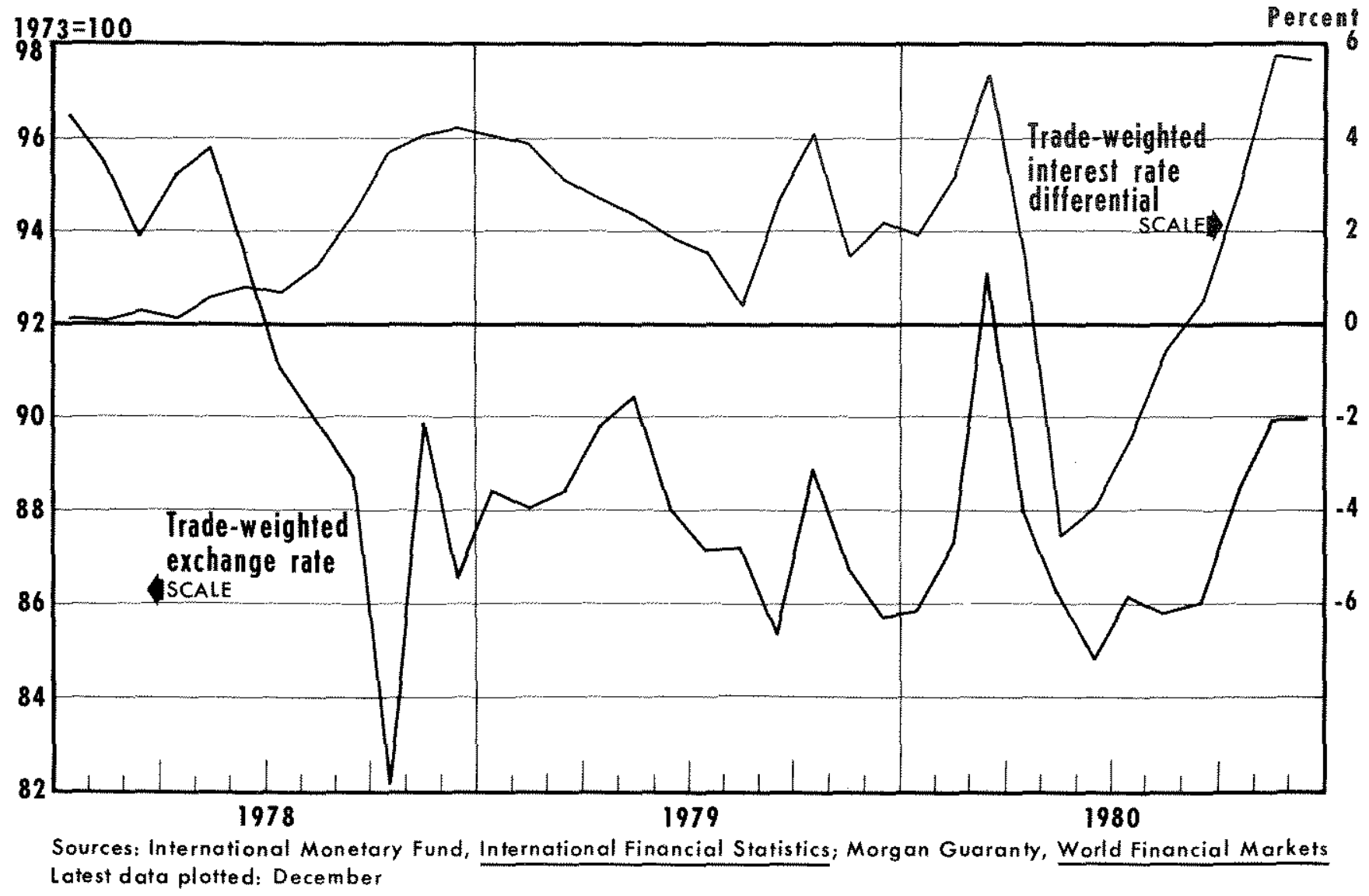

money growth and short-term interest rates have become increasingly volatile. Nonetheless, the Fed apparently has not accommodated the banking system's demand for reserves to the extent that it did when it targeted solely on the federal funds rate. Consequently, real interest rates have fluctuated relatively more and have been positively correlated with nominal interest rates since October 1979. This can be seen in chart 2 where the real interest rate is approximately the difference between the nominal interest rate and the expected rate of inflation.

One reason, then, why the value of the dollar has moved in the same direction as nominal interest rate differentials during 1980 is that, since the new monetary control procedure promoted higher real interest rate variability, changes in nominal interest rate differentials have been dominated by changes in real interest rate differentials. Consequently, the dollar and nominal interest rate differentials have moved in the same direction since October 1979. On the other hand, real interest rates were relatively stable compared to inflationary expectations during the previous period. Increasing money growth during this period led to a faster growth of inflationary expectations in the United States than abroad. The resulting relative increase in nominal interest rates reflected this relative increase in inflationary expectations, and the dollar fell even though nominal interest rate differentials rose.

This explanation can be verified by comparing the movement of the forward value of the dollar with nominal interest rate differentials. If the movement of U.S. nominal interest rates (and nominal interest rate differentials) during the I/1978 to III/1979 period was outweighed by relative changes in inflationary expectations, then nominal interest rate differentials and the forward dollar exchange rate should move in opposite directions ( that is, they should be negatively correlated). On the other hand, if changes in real in- 


\section{Chart 2}

\section{Nominal U.S. Interest Rate and Expected Inflation}

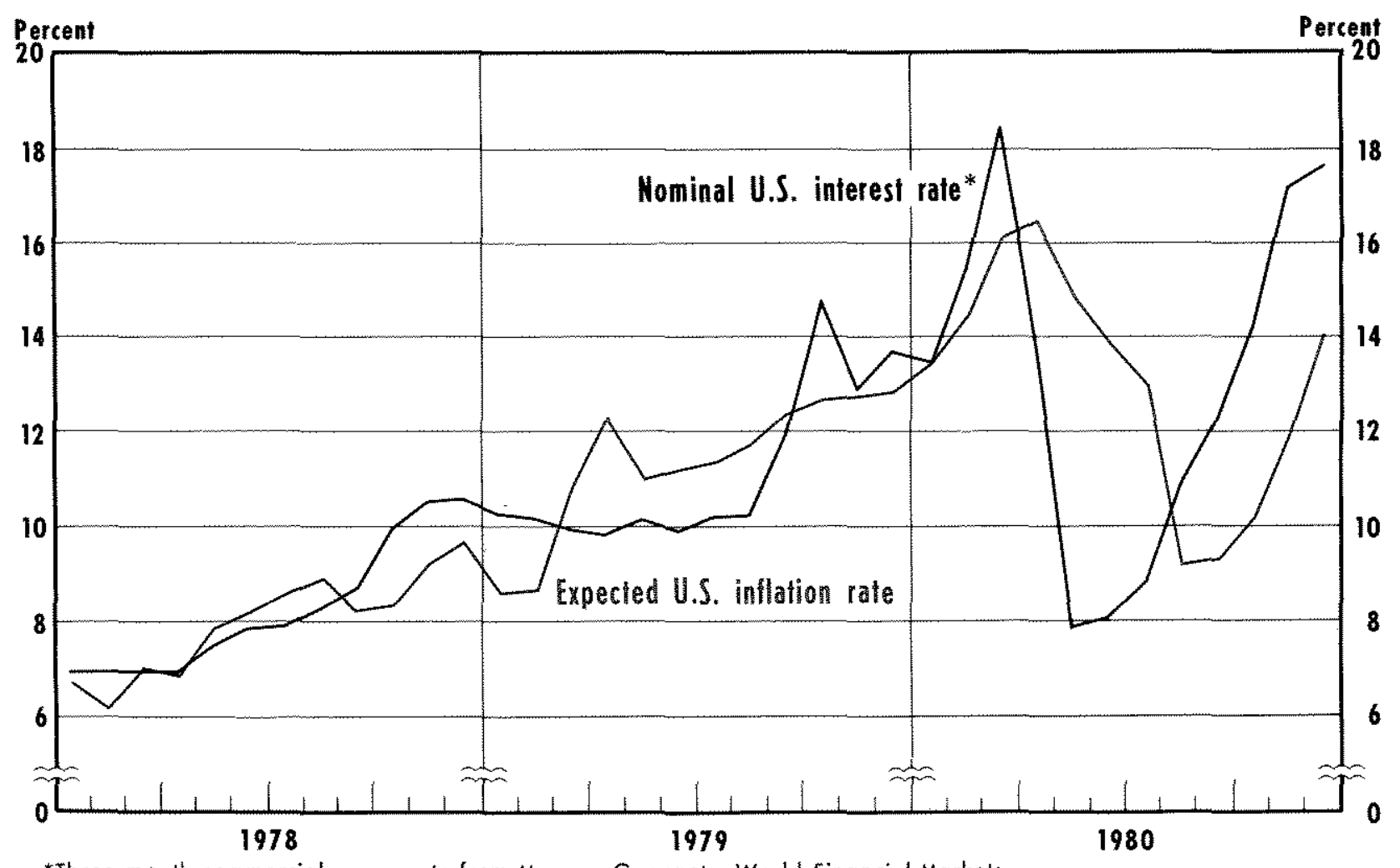

* Three-month commercial paper rate from Morgan Guaranty, World Financial Markets.

Latest data platted: December

terest rate differentials have been the dominant component of changes in nominal interest rate differentials, then there should be no significant relationship (that is, the forward dollar exchange rate should not be correlated with changes in nominal interest rate differentials).

Since the relationship between the dollar and the deutschemark is closely followed in foreign exchange markets, U.S./German interest rate differentials and the forward dollar/deutschemark exchange rate are used to test these hypotheses. ${ }^{11}$ In particular, changes in the difference between rates on three-month Eurodollar deposits and three-month Euromark deposits are compared with changes in the three-month forward deutschemark price of a dollar. The data show that neither hypothesis can be rejected; that is, during the period from January 1978 to September 1979 the Euro-

${ }^{11}$ Also, Germany's weight is the largest in the calculation of the trade-weighted value of the dollar. Consequently, changes in the dollar/deutschemark exchange rate have the largest impact on the trade-weighted value of the dollar.
dollar/Euromark interest rate differential and the three-month forward deutschemark price of a dollar did move in opposite directions. However, no significant relationship between these two variables has been exhibited for the period from October 1979 to December 1980.12

\section{CONFLICTING GOALS OF POLICYMAKERS}

In attempting to prevent (or at least mitigate) short-run exchange rate movements, some policymak. ers have been faced with incompatible external and internal goals, especially the apparent conflict between exchange rate stability and money growth stability. For example, if a government does not want the foreign value of its currency to rise, it can enter the for-

12The simple correlation coefficient between the Eurodollar/ Euromark interest rate differential and the three-month forward deutschemark price of a dollar is -.548 for the first period and .292 for the second. Critical values for the two periods are -.369 and .476 , respectively. 
eign exchange market and purchase foreign currency, using its own currency as payment. In essence, the government is increasing the demand for foreign currency, thereby causing its value to fall (or at least preventing it from rising). This action, however, also increases the domestic money supply, which has an inflationary impact on the economy. Since inflation is undesirable, these policy goals are incompatible. The best example of this conflict occurred in the United States in the spring of 1980.

By mid-March 1980 economic activity in the United States (and consequently loan demand) was beginning to weaken. This, along with the imposition of a credit control program, caused a sharp decline in interest rates beginning in early April and a precipitous fall in the value of the dollar. The Fed instantly intervened in the foreign exchange market, buying $\$ 1,013.8$ million from April 8 to April 23. Even with this intervention, the trade-weighted value of the dollar declined by 6 percent in this two-week period. At this time, those conducting domestic monetary policy attempted to thwart the fall in interest rates (and as a result support the dollar) by withdrawing $\$ 1,500$ million of reserves out of the banking system from April 23 to May 14. These two efforts to prevent the fall of the dollar prompted a dramatic decline in the domestic money stock and greatly exacerbated the already weakening level of economic activity. The result was a decline in real output at a 9.9 percent annual rate in the second quarter of $1980 .{ }^{13}$

\section{LONG-RUN MOVEMENTS OF THE FORETGN EXCHANGE VALUE OF TIE DOLLAR}

Up to this point, the analysis has concentrated on shorturun changes in the value of the dollar. In contrast to short-run movements of exchange rates, which are determined principally by events that occur within fnancial markets, long-run movements in exchange rates primarily reflect relative excesses in money growth above the amount demanded across countries. In this context, exchange rate movements depend on (1) policy changes that affect the rate of money growth and (2) real disturbances that affect money demand. Both have had a significant impact on the long-run movement of the dollar in the last two years. In particular, the 150 percent increase in oil prices

\footnotetext{
13Papid money growth followed this dedine in real CNP. The foreign desk impeded the domestic desk's ability to slow money growth by purchasing $\$ 5,813.1$ million equivalent of dentschemarks from July to the end of the year.
}

Table 1

\section{Annual Rates of Money Growth}

\begin{tabular}{|c|c|c|c|}
\hline country & $\begin{array}{l}\mathrm{V} / 1975 \\
\mathrm{~N} / 1978\end{array}$ & $\begin{array}{l}\mathrm{W} / 1978 \\
\mathrm{~V} / 1979\end{array}$ & U/1979 \\
\hline Belgum & $70 \%$ & $25 \%$ & $02 \%$ \\
\hline Canada & 79 & 49 & 88 \\
\hline Prance & 10,3 & 10.6 & 9.02 \\
\hline Germany & 10.1 & 44 & 45 \\
\hline taly & 22.2 & 252 & 9.6 \\
\hline Japan & 10.9 & 56 & -18 \\
\hline Netherlands & 8.1 & 4.5 & 5.2 \\
\hline sw/terland & 9.6 & 0.4 & -31 \\
\hline United Kingdon & 16.1 & 90 & 36 \\
\hline United States & 14 & 77 & 73 \\
\hline
\end{tabular}

The anmal rate of growth of MI is reported for each county except the United states for whid the MIB grow h rate is reported.

$210 / 1970111 / 1980$

since the beginning of 1979 was a primary contributor to the recessions (decline in real income) in most industrial nations during 1980 . In this respect the 1980 economic scenario was very similar to 1974 when oilimporting countries adjusted to sizable income transfers to oil-exporting countries. However, the recessions of 1980 were not as long or as severe. In fact, most major countries appear to have already reached the troughs of their recessions; Italy, the United Kingdom and Germany are the only nations for which the Organization for Economic Co-Operation and Development (OECD) expects continuing declines in real gross national product in $1981 .^{14}$ A general, secular decline in the rate of money growth has also accompanied this oil-price shock, as policymakers have attempted to check the inflationary pressure associated with the rise in oil prices (see table 1).

Since excessive money growth causes domestic prices to rise, the ramification of the oil shock and declining money growth on relative rates of excess money growth across countries can be ascertained by comparing relative rates of domestic inflation. Table 2 contains the difference between the 12-month rate of inflation in the United States and that of its major trading partners. Since the rate of inflation in the United States has improved relative to all countries except the United Kingdom in 1980, it appears that

14 Empirical support for these observations is included in OECD, Economic Outlook (December 1980), pp. 5-28. 
Table 2

Inflation Rate Differentials Between the United States and Selected Foreign Countries'

\begin{tabular}{|c|c|c|c|c|c|c|c|c|c|c|}
\hline 1980 & Belgium & Canada & France & Gormany & laty. & Japan & Nether & Sweden & Switzer & $\begin{array}{l}\text { United } \\
\text { Kingdorn }\end{array}$ \\
\hline Januaty & $8.2 \%$ & $46 \%$ & $1,2 \%$ & $9.2 \%$ & $6.4 \%$ & $76 \%$ & $86 \%$ & $16 \%$ & $92 \%$ & $4.2 \%$ \\
\hline February & 7.6 & 4.6 & 0.8 & 6.5 & -68 & 61 & 80 & 0.6 & 100 & $=5.0$ \\
\hline Mareh & 82 & 5.3 & 11 & 90 & 5.8 & 6.7 & 8.8 & 12 & 10.0 & -51 \\
\hline April & 8.2 & 5.5 & 0.9 & 89 & 62 & 6.3 & 83 & 11 & 10.6 & -7.1 \\
\hline May & 79 & 50 & 0.8 & 8.4 & $=6.4$ & 62 & 78 & 12 & 100 & 7.5 \\
\hline June & 82 & 41 & 0.9 & 8.3 & 6.6 & 6.9 & 77 & 1,3 & 111 & -6.7 \\
\hline July & 6.6 & 3,1 & -0.4 & 78 & 8.9 & 56 & 61 & 0.0 & 99 & -3.7 \\
\hline Aygust & 6.4 & 2.0 & -0.7 & 74 & 92 & 411 & 5.7 & 05 & 87 & -3.5 \\
\hline Seplember & 59 & 19 & -0.9 & 76 & 88,6 & 80. & 5.7 & 2.3 & 89 & 43 \\
\hline Pelober & 56 & 16 & -0.9 & 7.6 & 8.6 & 48 & 5.9 & 30 & 8.9 & -28 \\
\hline November & 5.0 & 1,4 & -0.9 & 72 & 9.4 & 4.2 & 5.9 & 2.0 & 8.3 & -2.6 \\
\hline December & 4.3 & 12 & -1.3 & 70 & 8,9 & 53 & 57 & 1.6 & 79 & -27 \\
\hline
\end{tabular}

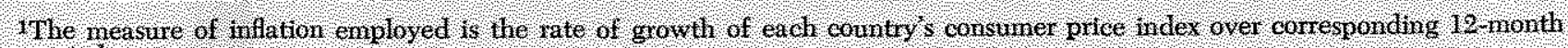
periods.

excess money growth is relatively slower in the United States than in these countries. Consequently, the value of the dollar in terms of the currencies of these countries (except the United Kingdom) should have risen during this period. The data contained in table 3 support this conclusion for all countries except Japan. That is, in all other cases, if the rate of inflation in the United States improved in relation to the other country, the dollar appreciated; if the rate of inflation in the United States worsened relative to the other country (as with the United Kingdom), the dollar depreciated.

Over the long run, the concept of purchasing power parity is a good indicator of the direction in which market fundamentals are pushing the exchange rate. Chart 3 contains the monthly deutschemark price of a dollar determined in the foreign exchange market and the deutschemark price of a dollar necessary to maintain purchasing power parity for 1979 and $1980 .^{15}$ Obviously, the two are not identical; this is due to the existence of trade barriers, transport costs and nontraded goods. Nonetheless, they are nearly equal, indicating that the longer-run movements in the dollar relative to the deutschemark have closely reflected relative changes in their rates of inflation. The move-

15 Since purchasing power parity is a long-run concept, the data were smoothed by calculating 12 -month moving averages.
Table 3

Annualized Rates of Change in the Price of a Dollar ${ }^{2}$

\begin{tabular}{|c|c|}
\hline eountry & $\begin{array}{l}\text { Decenber } 1979 \\
\text { December } 1980\end{array}$ \\
\hline Belgium & $124 \%$ \\
\hline Canada & 23 \\
\hline France & 12.3 \\
\hline Germany & 138 \\
\hline llaly & 153 \\
\hline Sapan & 128 \\
\hline Netherlands & 117 \\
\hline sweden & 5.5 \\
\hline switzerland & 116 \\
\hline Unted Krogdom & 6,1 \\
\hline
\end{tabular}

IA positive elange inlicates that the dollar has apprectated a hegat ve change indicates that the dollar has depreciated 


\section{Purchasing Power Parity and Market Exchange Rate}

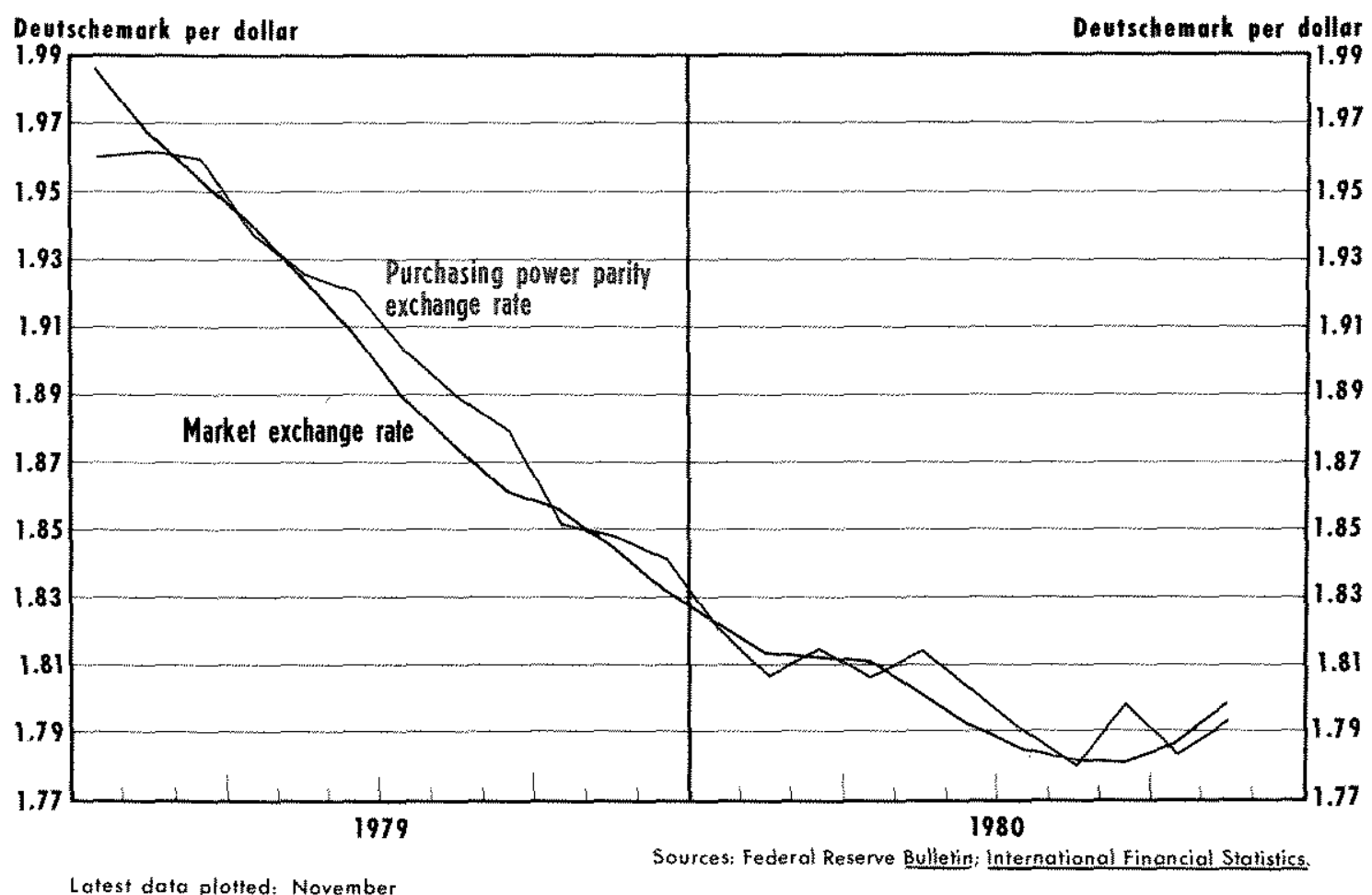

Latest dofa plotted: Navember

ment of the purchasing-power-parity exchange rate also provides a clear picture that excess money growth has been more rapid in the United States than in Germany during most of this period. Consequently, the dollar has been steadily depreciating relative to the deutschemark. However, at the end of 1980 , both the market exchange rate and the purchasing-powerparity exchange rate began to rise. Although it is too early to discern a change in trend, it seems that the long-run value of the dollar is beginning to strengthen.

\section{SUMMARY AND OUTLOOK}

This article has attempted to clarify some of the ambiguities concerning changes in the value of the dollar in 1980. In particular, the dollar has moved with nominal interest rate differentials during the year primarily because these changes have reflected changes in real interest rate differentials. Changes in nominal interest rate differentials prior to the third quarter of 1979 were motivated largely by relative changes in inflationary expectations. Consequently, the dollar and nominal interest rate differentials moved in opposite directions. This change in the complexion of changes in nominal interest rate differentials may have been due largely to the new procedures for monetary control implemented by the Fed in October 1979.

A longer-run analysis of the dollar shows (1) that the current deutschemark price of a dollar is consistent with its long-run purchasing-power-parity value and (2) that excess money growth in the United States may be slowing relative to its trading partners and, consequently, the long-run value of the dollar may be strengthening.

What can one expect about the value of the dollar in 1981? First, changes in the value of the dollar should only be as volatile as changes in real interest rates. This does not mean, however, that a fall in U.S. nominal interest rates will necessarily signal a decline in the dollar as many economists have predicted. Only if this decline reflects a fall in real interest rates will the value of the dollar fall. However, if the U.S. mone tary authorities are more successful than other central banks in controlling excess money growth (as the long-run analysis tentatively indicates), then a fall in nominal interest rates may indicate a deceleration of inflationary expectations in the United States relative to other countries, and the dollar should remain strong in 1981. 